\title{
Are Your Personal Financial Characteristics Healthy?
}

Dan Yates, University of Findlay, USA

Chris Ward, University of Findlay, USA

\begin{abstract}
This study set out to discover the key personal financial areas or "personal financial characteristics" that individuals should have a basic knowledge of as well as their ability to manage their personal finances. Once these areas were determined, a self-assessment survey was created. Upon completion of the survey, a total score can be determined to assess one's degree of personal financial healthiness. The study is important because the instrument can help identify problems areas that people have in managing their own personal finances. The self-assessment survey could be used by financial planners or financial counselors as they work with clients in becoming better stewards of their financial resources. The instrument also provides an action planning area to be used to identify areas for improvement.
\end{abstract}

Keywords: Personal Finance; Financial Literacy; Personal Finance Survey; Financial Counseling

\section{INTRODUCTION}

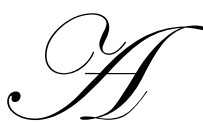

s our government struggles to manage its huge national debt and overspending habits, our society is taking a sincere interest in how the government will meet its obligations. Individuals are concerned that the government's poor financial condition may have a negative impact on them through increased taxes, higher interest rates, higher prices, etc. Some people are beginning to feel stress due to the uncertainty in the U.S. economy.

In a recent Associated Press (AP) survey (June, 2011), it was found that Americans' worries about personal finances are rising again and that debt-related stress was up 17 percent from the November 2010 AP survey. The June survey noted that married moms and adults under 30 years old showed significantly more anxiety than in the fall. The poll indicated that "more than 40 million Americans are feeling serious stress over the money they owe, whether it's for credit cards, mortgages, car loans or other debts" as reported by MoneyNews.com (July 25, 2011).

Being financially literate can have both financial and physical implications. Our study will focus on literacy competencies in an effort to provide assistance and direction for those interested in becoming more financially responsible.

In reviewing the literature pertaining to financial literacy, we examined studies relating to high school students, college students, and adults. The researchers were interested in determining the level of financial literacy among those groups. The research then moved to identifying the pertinent and common competency areas in personal financial literacy. We will first address the definition of financial literacy.

\section{What is "financial literacy"?}

In examining many different definitions of financial literacy, we will use the definition used by the U.S. Financial Literacy and Education Commission (2007). It defines financial literacy as “.....the ability to use knowledge and skills to manage financial resources effectively for a lifetime of financial well-being" (pg. 66). Supporting our earlier study (Yates and Ward, 2010), this definition utilizes the "application of financial knowledge" in making prudent decisions in managing one's financial resources. Being able to apply financial knowledge is the key to making informed and objective decisions. This study will help individuals to focus on the key financial related areas that they will use in making future financial decisions. 


\section{LITERATURE REVIEW}

\section{Studies Relating to High School Financial Literacy}

The members of the Jump\$tart Coalition have identified the key areas of coverage for the national survey which are based on their National Standards in K-12 Personal Finance Education (http://jumpstart.org/nationalstandards.html). The six key areas were: financial responsibility and decision making; income and careers; planning and money management; credit and debt; risk management and insurance; and saving and investing.

Since 1997, the National Jump\$tart Coalition has surveyed high school seniors in forty-seven states. The results have been disappointing ranging from 57.3\% in 1997 to 48.3\% in 2008 (Mandell 2009).

Below is a summary of the key results from the surveys:

- Students who take a high school course in personal finance performed no better on the exam than students who did not take the course.

- $\quad$ Students with higher incomes tended to have higher scores. It was the fourth time that students from families with the highest incomes performed better than all other groups which is supported by Valentine and Khayum's (2005) research.

- The survey results were also related to "parents' education level". The average score of students with neither parent completely high school was 44.2 percent and rose to 51.8 percent if at least one parent completed college. Mandell (2009) claims that families of students from higher income and better educated families may be placing a priority on the importance of financial literacy.

- $\quad$ Students taking courses in either personal finance or money management showed no improvement in their financial literacy scores.

- $\quad$ Students who played a stock market game in class did significantly better on the exam than other students with a full semester's course in money management.

Another study conducted by the National Council on Education (NCEE) in 2005 sampled high school students nationwide (U.S.). It was found that a majority of high school students do not understand the basic concepts in economics and personal finance. This lack of knowledge further complicates their ability to manage their personal finances and function in today's global economy. The quiz covered 20 economic content standards developed by the NCEE plus additional concepts relating to personal finance. The students' average score on the quiz was $53 \%$ or "F" and $60 \%$ of the high school students failed the quiz which supports the findings by Mandell's surveys that high school students are not financially literate.

Research by Godsted and McCormick (2007) found the "lack of teacher training" as a significant impediment to the inclusion of financial education into the curriculum K-12. This would suggest that the poor results on financial literacy surveys may be impacted to some degree by the students' teachers.

Nevertheless, the findings from the above mentioned surveys provide evidence that there is room for improvement in economic and personal financial literacy levels for high school students.

\section{Studies Relating to College Financial Literacy}

Peng, Bartholomae, Fox and Cravener (2007) study found that students who participated in a college level course with personal finance content had higher levels of investment knowledge. However, there was no significant relationship between taking a high school course and having investment knowledge. The results indicated that taking a personal finance course both in high school and in college was not correlated with higher investment knowledge scores. Participating in a college personal finance course appears to be more effective in enhancing investment knowledge than participating in a personal finance course at the high school level (Grabmeier, 2007). 
This finding may be the result of two factors:

1. College students may receive more details on investment topics than in a high school level course.

2. The results may be partially explained by the "teachable moment" maxim as college students take on greater levels of their personal financial responsibilities such as paying bills, working, credit card usage, savings, and managing student loans.

The knowledge gained through experiential learning may have more impact to the learning process of the college aged student. These results are supported by Mandell's first national survey to college students in 2008 .

Mandell (2009) notes that the scores improved for every year of college with seniors averaging 64.8 percent and states that American college graduates are close to becoming financially literate and probably will be with more "life experiences". Knowing how to approach problems and conduct research are key to making decisions regarding personal finance. These critical thinking skills are perhaps more apt to be learned in college than in high school personal finance classes.

Cude, Lawrence, Lyons, Metzger, LeJeune, Marks and Machtmes (2006) studied college students' financial management practices and their attitudes about financial management. The study found that students were more likely to be financially fit if they had higher GPAs or had married parents. Students were more "financially at-risk" if they had credit cards, were a minority, or a college senior. Cude et al's (2006) research noted that some college students are not managing their finances well because of not adopting a set of recommended practices. Cude (2006) recommends that some "recommended" financial practices be modified to more accurately match the ways college students responsibly manage their finances. Also, the study suggested that future researchers develop a scale of financial management responsibility that is fitting for college students' financial management options.

Our study begins to address the development of a "scale" or personal financial characteristics which may be beneficial for both college students and adults.

\section{Studies Relating to Adult Financial Literacy}

The 2010 Financial Literacy survey was conducted by Harris Interactive on behalf of the NFCC (National Foundation for Credit Counseling) in 2010 among 2,028 adults ages 18+. Table A identifies the various financial categories used by the survey along with the related findings:

\section{Table A: National Foundation for Credit Counseling Study Results}

\begin{tabular}{|l|l|}
\hline Financial Literacy & $\begin{array}{l}34 \text { percent of U.S. adults, or more than } 77 \text { million people living in America, gave themselves a grade } \\
\text { of C, D, or F on their knowledge of personal finance. This suggests there is room for improvement } \\
\text { with Gen Y adults at 39\% with the lowest grades and 43\% of the Gen Y strongly agreeing that they } \\
\text { could benefit from advice and answers to everyday-type financial questions. }\end{array}$ \\
\hline Budgets & $\begin{array}{l}11 \text { million adults (5 percent) don't know how much they spend on food, housing, and entertainment, } \\
\text { and do not monitor their overall spending. Among the 56\% of adults who do not have a budget, note } \\
\text { negative attitudes about budgeting which may reinforce unhealthy spending behaviors. }\end{array}$ \\
\hline Spending & $\begin{array}{l}51 \% \text { or roughly } 116 \text { million people reported spending less than they were a year ago and nearly 23\% } \\
\text { are spending a lot less. }\end{array}$ \\
\hline Savings & $\begin{array}{l}\text { One-third of adults (33 percent), or } 75 \text { million people, do not contribute to a retirement plan. 30\% } \\
\text { report that they have no savings and only 24percent are now saving more than they did a year ago due } \\
\text { to the economy. } 48 \% \text { of Gen Y adults report having no savings and 25\% of those would charge an } \\
\text { emergency type expense to a credit card or take out a loan. }\end{array}$ \\
\hline Debt and Credit Cards & $\begin{array}{l}28 \% \text { (more than } 64 \text { million adults) admit to not paying all of their bills on time and more than 11 } \\
\text { million adults (5 percent) report that their household carries credit card debt of } \$ 10,000 \text { or more each } \\
\text { month. }\end{array}$ \\
\hline Credit Score & $\begin{array}{l}\text { (65 percent) or } 148 \text { million people have not ordered a copy of their credit report in the past year despite } \\
\text { it being free. }\end{array}$ \\
\hline Housing & $\begin{array}{l}44 \% \text { of adults (more than } 100 \text { million people) currently have a home mortgage and with 33\% noting } \\
\text { they did not understand some of the terms of their mortgage. }\end{array}$ \\
\hline Retirement & $\begin{array}{l}\text { One-third of adults do not put any part of their annual household income toward retirement. Only 7\% } \\
\text { of adults save more than } 20 \% \text { of their income for retirement each year. }\end{array}$ \\
\hline
\end{tabular}


The study found that financial literacy was low among adults and $78 \%$ stated they could still benefit from advice about financial questions from a professional.

Most adults cannot perform simple economic calculations and do not have knowledge about the basic concepts of finance (Lusardi, 2008). Lusardi asserts that ignorance about basic financial concepts can be associated with the failure to participate in activities such as retirement planning, stock market, and may cause poor decisionmaking behavior when borrowing money (Lusardi and Mitchell, 2006).

The results of the literature review indicate there is room for improving the knowledge level for many adults. It would appear that those adults would benefit from the services of financial professionals to help guide them in making decisions on their personal finances. However, the cost of financial services may be prohibitive for many people. Having a personal financial reference guide that would provide information about the various areas of personal finance could have significant positive application for many adults.

As noted above, there is a real concern that financial knowledge is not progressing from high school students to adults. The next section will address those areas of personal finance that individuals should have a basic level of knowledge.

\section{Basic Knowledge Areas in Personal Finance}

The State of Ohio passed Senate Bill 311 that required the integration of economics and financial literacy within either social studies classes or another class. This bill was effective for freshmen who enroll in high school on or after July 1, 2010. Teacher academies were established by various universities designed to train educators to deliver instruction that would provide a comprehensive understanding of financial literacy.

The Jumpstart Coalition developed The National Standards in K-12 Personal Finance Education ( $3^{\text {rd }}$ Edition, 2007) for educators which included six different instructional areas. The content of the national standards are as follows: Income and Careers; Planning and Money Management; Credit and Debt; Risk Management and Insurance; and Saving and Investing.

An analysis of the content areas found in senate bill 311 and in the national standards curriculum was compared to four college level textbooks by Yates and Ward (2010). It was found that the textbooks did contain all of the content areas as found in both the senate bill and the national standards.

This would suggest that the same financial literacy topics are being addressed at both the high school and college levels.

Noted in Table A, the financial literacy topics for the 2010 Financial Literacy survey on behalf of the NFCC (National Foundation for Credit Counseling) included the following areas: financial literacy; budgets; spending; savings; debit and credit cards; credit score; housing; and retirement.

In reviewing personal financial content areas from various personal finance gurus such as Dave Ramsey, Suzie Orman, Larry Burkett, Howard Dayton, et al., they seem to agree on the common areas of personal financial importance noted above. Those areas are also supported by many of the financial education websites such as the Family Economics \& Financial Education (http://fefe.arizona.edu/) and The Mint (http://www.themint.org/teachers/budgeting-your-financial-resources.html).

After reviewing the literature on financial literacy, the following common personal finance knowledge topics were determined: emergency funding; saving and spending plans; using credit effectively; consumer debt; home mortgage debt; building wealth; financial planning and risk management; retirement planning; saving for children's education; and estate planning.

Researchers have struggled in developing an adequate measure of financial literacy. Although Huston's (2010) analysis of various studies found no standardized instruments to measure financial literacy, perhaps the common personal finance knowledge topics noted above would suffice. Huston notes several barriers to developing 
a standardized approach in measuring financial literacy, one being the lack of content of an instrument. It is the intent of our research to present a starting point in developing an instrument that begins to address the critical areas of personal finance that are relevant to all individuals.

\section{METHODOLOGY}

\section{Assessment tool (survey)}

The assessment tool or survey is entitled: "Personal Financial Characteristics: Healthy vs. Unhealthy". The key criteria used in the survey were: emergency fund; saving and spending plan; effective use of credit; consumer debt; personal home mortgage; building wealth; financial planning and risk management; retirement plan; children's education; and estate planning. Each key criterion was further defined by Healthy; Moderately Healthy; and Unhealthy. The criteria and their definitions were developed by the authors based upon the research of the literature and from the review from an external group of finance and accounting college professors, financial consultants, and several college educated adults.

\section{Research questions}

The following research questions were posed to establish a preliminary baseline for the pilot study:

1. What was the overall average score on the survey from the pilot group?

2. What are the average scores for each of the personal financial characteristic areas for the pilot group?

3. Which personal financial characteristics were selected by the pilot group to be improved upon from the action plan?

\section{Survey Scorecard}

The participants rated each criterion based on the following scale:

$\begin{array}{lll}\text { - } & \text { Rating } & \text { Points } \\ \text { - } & \text { Healthy } & 8-10 \\ \text { - } & \text { Underately Healthy } & 4-7 \\ & \text { Unhealthy } & 1-3\end{array}$

Each participant would total their points on their scorecard. Total survey scores ranging from 80-100 were considered in "Excellent" health; scores ranging from 40-79 were considered "Moderately" healthy; and scores from 10-39 were considered "Unhealthy".

\section{Test group}

This study was a pilot study and was tested by twenty-one volunteers who participated in a personal finance workshop conducted by the researchers at a church. The collection of data was self reported by each participant. The personal characteristics instrument survey was explained in detail for each criterion explaining the parameters of healthy, moderately healthy, and unhealthy. Each participant then indicated a score by circling the appropriate number on the evaluation sheet. Upon completion of the survey, each participate totaled their recorded scores. The participants then completed the action step phase of the survey to identify those areas that needed improvement. Upon completion of the overall survey, each participant completed the recap sheet which identified the scoring for each criterion along with other demographic information (i.e., age, gender, and marital status). They also identified which of the key areas for improvement from the Action Plan that they plan to address in the future. 


\section{RESULTS}

Research question 1: What was the overall average score on the survey from the pilot group?

$\begin{array}{lll}\text { Survey results } & \frac{\text { Mean Average }}{79.7} & \frac{\text { Standard Deviation }}{16.1}\end{array}$

Research question 2: What are the average scores for each of the personal financial characteristic areas for the pilot group?

The chart below lists the average mean score and standard deviations by each of the key criteria from the survey.

\begin{tabular}{lcc} 
Key Criteria & Mean Average & Standard Deviation \\
\cline { 2 - 3 } Emergency Fund & 7.1 & 2.6 \\
Saving and Spending Plan & 8.3 & 1.6 \\
Credit Cards & 9.2 & 1.0 \\
Consumer Debt & 8.5 & 1.7 \\
Personal Home Mortgage & 8.4 & 1.5 \\
Building Wealth & 8.2 & 1.9 \\
Financial Plan/Risk Mgt. & 7.6 & 2.1 \\
Retirement Planning & 7.8 & 1.8 \\
Children's Education & 7.9 & 3.1 \\
Estate Planning & 6.6 & 3.2 \\
TOTAL SCORE & 79.7 & 16.1
\end{tabular}

Research question 3: Which personal financial characteristics were selected by the pilot group to be the most important areas to be improved upon from the action plan?

The chart below lists each of the key criteria from the survey and the percentage that were selected to be improved upon from the action plan.

\begin{tabular}{lc} 
Key Criteria & Percentage \\
\hline Emergency Fund & $30 \%$ \\
Saving and Spending Plan & $15 \%$ \\
Credit Cards & $5 \%$ \\
Consumer Debt & $0 \%$ \\
Personal Home Mortgage & $0 \%$ \\
Building Wealth & $0 \%$ \\
Financial Plan/Risk Mgt. & $5 \%$ \\
Retirement Planning & $5 \%$ \\
Children's Education & $10 \%$ \\
Estate Planning & $30 \%$
\end{tabular}

\section{LIMITATIONS}

The pilot survey sample was very small with twenty-one participants. The limited number of data points prevented further analysis of the average scores by marital status and by age groups.

\section{DISCUSSION}

The overall survey average score of eighty (80) would indicate that the pilot group was at the low-end of the excellent health scale. This is surprising due to the recent history of financial troubles indicated earlier in the literature review. 
The key criterion that the study group scored the highest was credit cards at 9.2 points and was closely followed by consumer debt, personal home mortgage, saving/spending plans, and building wealth which all had an average score over eight (8) points. The two lowest scores were found in estate planning and emergency fund (6.6 and 7.1, respectively). These low scores support that thirty percent (30\%) of the participants selected both the estate planning and emergency funds as areas to be addressed on their action plans. Although the average survey score was about 80 or Healthy level, there is a concern about the range of scores due to the very high standard deviation of 16.1. Several of the lower scores ( 49 and 56) present some potential financial issues for those participants.

Another concern of the researchers is to what extent are the participants doing what they say they are doing on the survey. For example, a score of 95 would indicate that the person is very healthy in terms of their personal finances. However, how much are they actually saving, is that enough, what is their current net worth, what are their retirement financial goals, are they on track to meeting those goals?

Future research needs to address these questions as part of the survey tool. The data obtained from those questions above will provide additional validation that people are doing what they say. The behavior based saving information will move the current survey tool to the next level.

\section{AUTHOR INFORMATION}

Dr. Ward is an associate Professor of Business with The University of Findlay. Professor Ward brings her expertise from two Fortune 500 companies into the classroom teaching operations and logistics, marketing, management, strategy and policy, communications, and research.

Professor Ward holds the following degrees: University of Sarasota, Ed.D., Organizational Leadership; The University of Findlay, MBA and The University of Findlay, Bachelor of Science in Business Administration. She is also a Six Sigma Black Belt, a 2008 Ohio Partnership for Excellence Examiner, and completed the NxLevel Certification Course for Instructor Certification for teaching business plans. Her areas of research include student engagement, active learning, assessment and promotion and tenure. E-mail: cward@ @indlay.edu

Dan Yates is an associate professor of business at The University of Findlay. His teaching interests include personal finance, entrepreneurship, leadership, organization development, and business strategy. Yates holds a PhD degree in Management from Northcentral University. He also has a MBA from University of Dayton, a Master of Organization Development degree from Bowling Green State University, and a BS in Accounting from Tiffin University. He completed the NxLevel Certification Course for Instructor Certification for teaching business plans at the Innovation Center (Ohio University). He has 30 years industrial and governmental experience. E-mail: Yates@Findlay.edu. Corresponding author.

\section{REFERENCES}

1. AP-GfK Poll: Worries About Debt Rising Once Again. (2011, July 25). Retrieved September 12, 2011, from Moneynew: http://www.moneynews.com/InvestingAnalysis/US-AP-GfKPollStressingOverDebt/2011/07/25/id/404742

2. $\quad$ Cude, B. J., Lawrence, F. C., Lyons, A. C., Metzger, K., LeJeune, E., Marks, L., et al. (2006). College Students and Financial Literacy: What They Know and What We Need to Learn. Eastern Family Economics and Resource Management Association Conference Proceedings, (pp. 102-109). Knoxville, TN.

3. Godsted, D., \& McCormick, M. H. (2007). National Adult Financial Literacy Research Overview. Indianapolis: Networks Financial Institute.

4. Grabmeier, J. (2007, August 9). Personal Finance Classes Help More in College Than High School. Retrieved August 27, 2010, from The Ohio State University Research News: http://researchnews.osu.edu/archive/finclass.htm

5. Huston, S. J. (2010, June 22). Measuring Financial Literacy. Journal of Consumer Affairs.

6. $\quad$ Lusardi, A. (2008, June). "Financial Literacy: An Essential Tool for Informed Consumer Choice?". Dartmouth College, Harvard Business School, and NBER. 
7. Lusardi, A., \& Mitchell, O. S. (2006). Financial Literacy and Planning: Implications for Retirement Wellbeing. Working Paper. Pension Research Council, Wharton School, University of Pennsylvania.

8. Making the Case for Financial Literacy-2010. (2010). Retrieved from JumpStart: www.jumpstart.org/assets/files/MakingtheCase2010\%201.doc

9. $\quad$ Mandell, L. (2009). Retrieved September 7, 2011, from Jumpstart.org: http://www.jumpstart.org/survey.html

10. National Council on Economic Education. (2005). What American Teens \& Adults Know About Economics. New York: National Council for Economic Education.

11. Peng, T.-C. M., Bartholomae, S., Fox, J. J., \& Cravener, G. (2007). The Impact of Personal Finance Education Delivered in High School and College Courses. Journal of Family and Economic Issues , 265284.

12. Survey of the States Report Reveals Pressing Need for Economic and Financial Literacy in U.S. School Systems. (2009, December 1). Retrieved September 8, 2010, from Council for Economic Education: http://www.councilforeconed.org/news/story.php?story id=174

13. The Associated Press-GfK Poll-June 2011. GfK Roper Public Affairs \& Corporate Communications.

14. The National Foundation for Credit Counseling. (2010). The 2010 Consumer Financial Literacy Survey Final Report. Silver Spring: The National Foundation for Credit Counseling; Harris Interactive Inc.

15. The National Standards in K-12 Personal Finance Education. (2007). Retrieved September 12, 2011, from Jumpstart.org: http://www.jumpstart.org/assets/files/standard book-ALL.pdf

16. Valentine, G. P., \& Khayum, M. (Winter, 2005). Financial Literacy Skills of Students in Urban and Rural High Schools. The Delta Pi Epsilon Journal, Vol. XLVII; 1-10.

17. Yates, D., \& Ward, C. (2011). Financial Literarcy: Examining the knowledge transfer of personal finance from high school to college to adulthood. American Journan of Business Education, January 2011, Vol. 4, No.1. 